\section{Bulking agents}

\author{
G Ucciero *, G Azzarito, G Costanzo, R Damiano \\ From de Senectute: Age and Health Forum \\ Catanzaro, Italy. 5-7 December 2009
}

\section{Background}

Stress urinary incontinence (SUI) is a common health problem affecting women and interfering with their quality of life. Many therapeutic options are available to solve this problem: conventional surgery, minimally invasive surgery, endoscopic procedures. The use of bulking agents for urethral augmentation seems to be a beneficial way of restoring continence in these patients while avoiding the risks of surgical intervention.

\section{Materials and methods}

We reviewed the literature to provide an update on the use of bulking agents. Moreover we have compared the use of bulking agents with other treatments for SUI. The results of the single procedure, follow up time, complications, and patient satisfaction are analyzed. The bulking agents considered are: bovine collagen, carbon beads, dexstranomer microspheres, porcin dermal,silicone PDMS, silicone microbaloons, ethylene vinyl.autologous fat. We have found 61 original papers from 1998 to 2009 (4191 patients) according to our criteria research.

\section{Results}

Global results showed a positive outcome in $77.5 \%$ with $38.7 \%$ (7-83\%) cured and $38.8 \%$ (9-77\%) improved. The mean follow up was $18.57(2-60)$ months.

\section{Discussion}

Many variables make data non omogenous. First of all, the choice of bulking agent used; secondly, the injecton technique can be periurtehral, transurethral or sovrapubic (in some cases). Thirdly, the site of the injection can be various: bladder neck, proximal urethra and mid urethra. The sex of patients and the age are other differences. Moreover, the type of stress urinary incontinence (SUI) (urethral hypermobility or intrinsic sphincter deficiency) as its association with bladder instability can be

Chair of Urology, University Magna Graecia of Catanzaro, Italy different. Also patients may or may have undergone previous surgery for SUI. Finally, it may have been necessary to repeat the injectons more than one time. Despite this inhomogeneity of casuistry, this remains highly indicative regarding the effectiveness of the procedure of bulking agent injection.

\section{Conclusions}

The injection of bulking agents is an attractive treatment option for SUI in view of their safe side effect profile. Their efficacy will improve with further technological advancements and the development of new ideal agents.

\section{Published: 19 May 2010}

\section{References}

1. M Haverkorn Rashel, Gomelsky Alex: Bulking Agents for Stress Urinary Incontinence : Are They Still Indicated? Current Bladder Dysfuction Reports 2008, 3(z):26-31.

2. Lindsey A MD: Bulking Agents in the Treatment of Stress Urinary Incontinence: History, Outcomes, Patient Populations, and

Reimbursement Profile. Reviews in Urology 2005, 7(Suppl 1):S3-S11.

doi:10.1186/1471-2318-10-S1-A81

Cite this article as: Ucciero et al:: Bulking agents. BMC Geriatrics 2010 10(Suppl 1):A81.

\section{Submit your next manuscript to BioMed Central and take full advantage of: \\ - Convenient online submission \\ - Thorough peer review \\ - No space constraints or color figure charges \\ - Immediate publication on acceptance \\ - Inclusion in PubMed, CAS, Scopus and Google Scholar \\ - Research which is freely available for redistribution \\ Submit your manuscript at www.biomedcentral.com/submit}

